International Journal of Applied Research 2021; SP6: 13-17

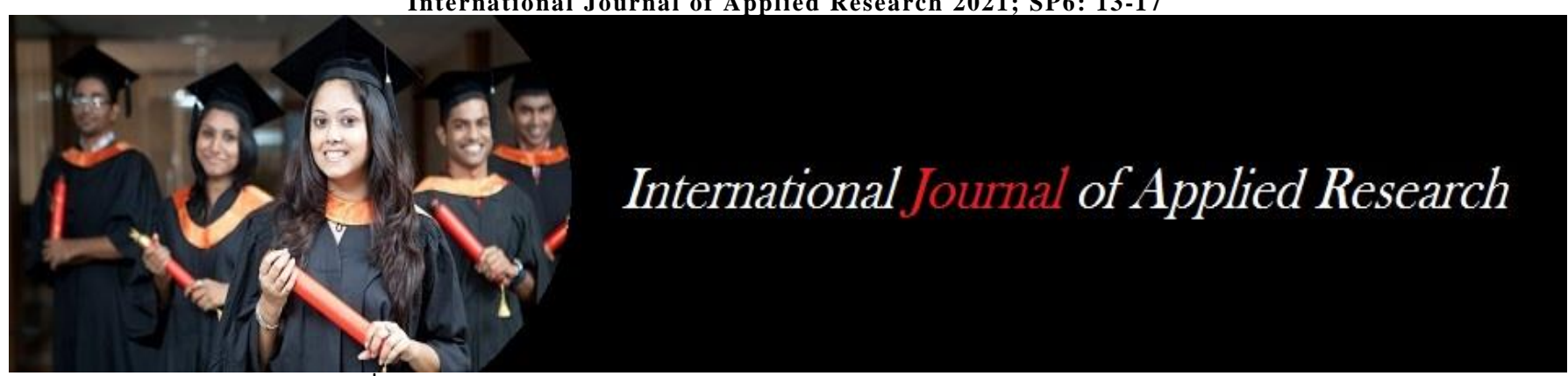

ISSN Print: 2394-7500

ISSN Online: 2394-5869

Impact Factor: 8.4

IJAR 2021; SP6: 13-17

Dr. Ranjith Somasundaran

Chakkambath

Asst. Professor, AMITY Global

Business School Kochi, Kerala,

India

Andrew Mathew Jose

Student-MBA, AMITY Global

Business School Kochi, Kerala,

India
Correspondence

Dr. Ranjith Somasundaran

Chakkambath

Asst. Professor, AMITY Global

Business School Kochi, Kerala,

India
(Special Issue)

"Impact and approach to pandemic covid-19 on various sectors"

\section{Post Covid impact of E-commerce on consumers}

\section{Dr. Ranjith Somasundaran Chakkambath and Andrew Mathew Jose}

DOI: https://doi.org/10.22271/allresearch.2021.v7.i6Sa.8602

Abstract

India has become one of the growing hubs of e-commerce. The Asia based surveys show that the after the pandemic, the frequency of weekly purchase has increased from twelve percentage before Covid to seventeen percentage online purchase after the pandemic. The internet usage in India has reached more than six hundred million by Jan 2021 according to report. The expected growth of e-commerce in India is two hundred billion by 2026. This is evident of the growth that is happening even during this Pandemic period in online purchase. This research paper tires to extract the factors that led to online purchase in this pandemic period. The findings were similar to some previous studies done in this area which supported scope of this research. The association between gender and preference for online purchase was also tested. The test done were Factor analysis and Chi Square test using SPSS 23. The findings brought out the factors like- convenience, payment options, offers etc which were some of the key variables in online purchase.

Keywords: E-commerce, pandemic, factor analysis, chi square test, convenience

\section{Introduction}

E-commerce was instituted back in the 1960s, with the coming up of electronic trade - the purchasing and selling of products through the transmission of information - which was made conceivable by the presentation of the electronic information exchange. Quick forward fifty years and web-based business has changed the manner by which society sells products and enterprises. Internet business includes something beyond having a brand name and selling items on the web. Finding the correct objective crowd, item specialty, and interfacing with your clients is fundamental since it permits you to reduce down pointless expenses and give items that are generally appropriate for your client base.

Internet business has gotten perhaps the most well-known strategies for bringing in cash on the web and an appealing chance for financial backers. For those keen on purchasing an online business, this article serves to give a prologue to internet business, covering the purposes behind its fame, the primary appropriation models and an examination of the significant internet business stages accessible.

The internet penetration in India is at $45 \%$ by Jan 2021 as per reports published. The number of mobile connections is equivalent to almost three by fourth of the total population in India ${ }^{[1]}$. This research paper investigated the usage of these online platforms for purchase during the pandemic. The overall spread of the COVID-19 pandemic has disturbed how individuals purchase items and administrations and how they see web-based business. The normalized lockdown rules across India and the developing dithering among purchasers to head outside and search for fundamental merchandise have shifted the country towards online business. Customers have changed from shops, grocery stores, and shopping centers to online gateways for the acquisition of items, going from fundamental wares to marked merchandise. Since the standard of social separating has been started for practically the aggregate of 2020, the extent of online buys and online organizations is required to flood. Numerous individuals are accepting the idea of online retail and the flood in FTUs (First Time Users) on internet business destinations is obvious. 
Certain reports suggest that the Covid rise will lead to more increase in the percentage of online purchase from the current forty-six percentage to sixty-four percentage over the coming 6 to 9 months. Majority of the consumers prefer to purchase from retailers who will provide delivery assurance and also assurance of compensation for future order cancellation ${ }^{[2]}$.

Global shoppers are expected to spend $20 \%$ more online in 2021 than they did last year, according to an Adobe report that was released in April 2021, likely adding pressure to supply chains as they struggle to keep up with a surge in demand. Due to spike in Covid and less number of vacancies around the world, Retailers have shut many of their physical stores and are now investing in online platforms ${ }^{[2]}$.

\section{Review of Literature}

Chandrakanth Urne et al. (2016) [3], identified that today internet business has become large and blasting industry and is producing gigantic business through e-exchanging ${ }^{[3]}$. The fast development of E-trade area massively affects market. The achievement of internet business thoroughly relies upon the reactions of customers and their purchasing conduct. Marked down center degree of business, serious estimating and entryway step conveyance are the keys of accomplishment. Indian market is considered as possible market as internet business is removing colossal business from the equivalent. This examination plans to contemplate the current accessible writing on online business and its connected investigations. The examination centers around the situation with e-commerce in India, web-based innovation appropriation, the financial effect of web-based business, web-based business and customer purchasing dynamic and online business advantages and its prosperity. Pandey and Parmar (2019) ${ }^{[4]}$, aimed to investigate the factors affecting consumer's online shopping behavior. The study results suggest that consumers' online shopping behavior is being affected by several factors like demographic factors, social factors, consumer online shopping experience, knowledge of using internet and computer, website design, social media, situational factors, facilitating conditions, product characteristics, sales promotional scheme, payment option, delivery of goods and after sales services are critical in online shopping ${ }^{[4]}$.

Mansour Abdelrhim (2020) as part of research explored the impacts of the spread of COVID-19 on worldwide online business organizations, where the five biggest internet business organizations on the planet were picked regarding incomes and market worth. The results indicate that the global e-commerce market is affected by the spread of the coronavirus and the independent variables were the most important and influencing the returns of the shares of global e-commerce companies, the variable (total deaths) was the degree of its impact in the first rank, and in the second rank a variable (total cases) and in the third rank Variable (new cases) ${ }^{[5]}$.

A report published by Orion Market Research Private Limited (2020), in relation to impact of Covid-19 on ecommerce market looks into the elements which drive the development of the online market before the COVID-19 pandemic incorporate solid and consistent development of web clients and rising mindfulness identified with internet shopping, expanding web-based dispatching of items, low cost because of mass buy, etc. The factors which resulted in the broadening of the e-commerce sector before the pandemic-19 included expansion in the number of internet users along with increase in awareness of online shopping products, the offers available through bulk purchase etc. The exclusive products market and the economies of scale were added factors which led to global e-commerce market ${ }^{[6]}$.

Post the COVID-19 pandemic, social removing and staying back at house is additionally expected to push the purchasers towards web-based shopping. Unsure buyer interest and inventory network issues can influence the internet business industry. The COVID-19 pandemic issue can likewise influence enormous dealers are facing a drop in easygoing shopping, store network disturbance, and an increment in acquisition of fundamental toiletries, goods, and different items.

Vikram P Balekar (2020) tried to study how Corona infection has affected the Indian economy-commerce, education and even employment. The research highlights the e-commerce status that there pre-Covid and suggests how India could prepare to compete with Global players like China who are leading in e-commerce. Hence, the current article endeavors to investigate the impact of novel Covid, its transmission in India, examines its effect and furthermore tries to propose different approaches to defeat this uncommon circumstance on different perspectives from economy to work and web-based business to training ${ }^{[7]}$.

The report named - 'E-commerce Trends Report 2020' centers around the development of online business in India alongside enumerating out changing customer conduct and the business reaction to address the recently arising online business patterns. The report mentions the pre-covid ecommerce growth in India which showed a growth of twenty percentage with healthcare, pharma, FMCG and agriproducts showing growth prospects. Post-Covid, when e-commerce began to rise up in its operations, the growth continued at seventeen percentage after the setback during lockdown period. The Pharma, Helathcare and FMCG sectors flourished during post lockdown period ${ }^{[8]}$.

Nakhate and Jain (2020), aimed to find effect of coronavirus one commerce. Most of the kits are manufactured in China and hence, dependability is remarkable. With effect of coronavirus, all the shipments processes are hindered which lowered the e commerce growth of country and state. The research paper here comprises of the impact of the corona virus on the online business of India. On the analysing, it has found that online businesses are seriously hampered due to this pandemic disease ${ }^{[9]}$.

Hasanat, et al. (2020), aimed to find out the effect of coronavirus (Covid-19) on internet business in Malaysia.. This search has been cleared and the basic search has been done to get a better result. The results showed that since the maximum number of products comes from China and the maximum industries are closed, which means that there is no import and export of the product ${ }^{[10]}$.

\section{Research Methodology}

Statement of the problem: E-commerce is gaining a lot of importance among the consumer post the pandemic. There are various factors that contributes to why consumers are opting online shopping. This research studies how the outbreak of Covid-19 led to the rise of e-commerce and its impact on consumers. 
Objectives of the study: To study the factors influencing online shopping during the pandemic.

Hypothesis of the study: $\mathrm{H}_{0}$ : Gender does not influence on choosing the online shopping platform

Research Design: The research design adopted for the purpose of study is descriptive in nature.

Sampling method: Convenient sampling method used to collect information is convenient sampling through

questionnaires. The sample is made of online shoppers in Kochi.

Sample Size: The sample size selected for this research is 122.

Data Collection method: A structured questionnaire designed using Google forms were used for executing this survey.

\section{Results and Discussion}

Table 1: Demographic Details

\begin{tabular}{|c|c|}
\hline Demographic characteristic & \multirow{2}{*}{ Percentage of Respondents (\%) } \\
\hline Age Group & \\
\hline $20-30$ & 47.5 \\
\hline $31-40$ & 24.6 \\
\hline $41-50$ & 20.5 \\
\hline 51 and above & 7.4 \\
\hline \multicolumn{2}{|c|}{ Gender } \\
\hline Male & 45.9 \\
\hline Female & 54.1 \\
\hline \multicolumn{2}{|c|}{ Level of Education } \\
\hline SSLC/10th & 14.2 \\
\hline Plus Two & 19.8 \\
\hline Under Graduate & 32.1 \\
\hline Post Graduate & 33.9 \\
\hline \multicolumn{2}{|c|}{ Occupation } \\
\hline Student & 27.9 \\
\hline Business & 12.3 \\
\hline Salaried & 48.4 \\
\hline Homemaker & 8.2 \\
\hline Retired & 3.2 \\
\hline \multicolumn{2}{|c|}{ Monthly Family Income } \\
\hline Below Rs 20000 & 25.4 \\
\hline Rs 20001 - Rs 35000 & 23 \\
\hline Rs 35001 - Rs 50000 & 22.1 \\
\hline Rs 50001 and above & 29.5 \\
\hline
\end{tabular}

The summary of the demographic profile in Table 1 reveals that most of the respondents who prefer online shopping fall within the age group of $20-30(47.5 \%)$ with a majority of respondents being females $(54.1 \%)$. An interesting observation is that more than half of the online shoppers surveyed are below the age of 40 years. The majority of respondents $(32.1 \%)$ are graduates. Nearly two-thirds of the respondents are either self-employed or salaried individuals. Almost half of the online shoppers in the sample have a monthly family income of between Rs.20000 to 50000 .

a) Chi Square Test: Gender Vs Preference of online shopping platform

Table 2: Chi square Test

\begin{tabular}{|c|c|c|c|c|c|c|}
\hline \multicolumn{7}{|c|}{ Gender * Which online platform do you prefer shopping from? Crosstabulation } \\
\hline \multicolumn{7}{|c|}{ Count } \\
\hline & & \multicolumn{4}{|c|}{ Which online platform do you prefer shopping from? } & \multirow[b]{2}{*}{ Total } \\
\hline & & Ajio & Amazon & Flipkart & Myntra & \\
\hline \multirow{2}{*}{ Gender } & Female & 1 & 29 & 22 & 3 & 55 \\
\hline & Male & 1 & 33 & 31 & 1 & 66 \\
\hline \multicolumn{2}{|c|}{ Total } & 2 & 62 & 53 & 4 & 121 \\
\hline
\end{tabular}

Table 3: Chi-Square Tests

\begin{tabular}{|c|c|c|c|}
\hline & Value & df & Asymptotic Significance (2-sided) \\
\hline Pearson Chi-Square & $1.801^{\mathrm{a}}$ & 3 & .615 \\
\hline Likelihood Ratio & 1.839 & 3 & .606 \\
\hline N of Valid Cases & 121 & & \\
\hline a. 4 cells (50.0\%) have expected count less than 5. The minimum expected count is.91. \\
\hline
\end{tabular}

$\mathrm{H}_{0}$ : Gender does not influence on choosing the online shopping platform.
The results of the Chi-Square tests for age and the various platforms are described in Table 2 and Table 3. The 
significance value is greater than.05. Hence, we accept the null hypothesis. We conclude that gender has no influence on choosing the online shopping platform.

A study done by Dhara $\mathrm{H}$ Mevada found that there was no association between purchase behaviour and gender ${ }^{[11]}$. V. Andal and G. Mythili, investigated and came to the interesting find that there was no association between gender and convenience of shopping which was related to online shopping ${ }^{[12]}$. A contradiction of this was reported by Suchitra Rani et al., found there was association between gender and online purchase preference. Rani, T. S., \& Sripathi, N. (2017) ${ }^{[13]}$. b) Factor Analysis: Factors related to online purchase during Pandemic

Table 4: KMO and Bartlett's Test

\begin{tabular}{|c|c|c|}
\hline \multicolumn{2}{|c|}{$\begin{array}{c}\text { Kaiser-Meyer-Olkin Measure of Sampling } \\
\text { Adequacy. }\end{array}$} & $\mathbf{. 7 4 9}$ \\
\hline \multirow{2}{*}{$\begin{array}{c}\text { Bartlett's Test of } \\
\text { Sphericity }\end{array}$} & Approx. Chi-Square & 447.432 \\
\cline { 2 - 3 } & Df & 91 \\
\cline { 2 - 3 } & Sig. & .000 \\
\hline
\end{tabular}

Table 5: Total Variance Explained

\begin{tabular}{|c|c|c|c|c|c|c|c|c|c|}
\hline \multirow{2}{*}{ Component } & \multicolumn{3}{|c|}{ Initial Eigenvalues } & \multicolumn{3}{|c|}{$\begin{array}{c}\text { Extraction Sums of Squared } \\
\text { Loadings }\end{array}$} & \multicolumn{3}{|c|}{$\begin{array}{c}\text { Rotation Sums of Squared } \\
\text { Loadings }\end{array}$} \\
\hline & Total & $\begin{array}{c}\% \text { of } \\
\text { Variance }\end{array}$ & Cumulative \% & Total & $\begin{array}{c}\% \text { of } \\
\text { Variance }\end{array}$ & $\underset{\%}{\text { Cumulative }}$ & Total & $\begin{array}{c}\% \text { of } \\
\text { Variance }\end{array}$ & $\begin{array}{c}\text { Cumulative } \\
\%\end{array}$ \\
\hline 1 & 6.175 & 61.750 & 61.750 & 6.175 & 61.750 & 61.750 & 4.888 & 48.877 & 48.877 \\
\hline 2 & 1.053 & 10.535 & 72.285 & 1.053 & 10.535 & 72.285 & 2.341 & 23.408 & 72.285 \\
\hline 3 & .934 & 9.341 & 81.626 & & & & & & \\
\hline 4 & .621 & 6.210 & 87.836 & & & & & & \\
\hline 5 & .488 & 4.882 & 92.718 & & & & & & \\
\hline 6 & .396 & 3.960 & 96.678 & & & & & & \\
\hline 7 & .177 & 1.766 & 98.444 & & & & & & \\
\hline 8 & .156 & 1.556 & 100.000 & & & & & & \\
\hline 9 & $2.690 \mathrm{E}-17$ & $2.690 \mathrm{E}-16$ & 100.000 & & & & & & \\
\hline 10 & $-6.024 \mathrm{E}-16$ & $-6.024 \mathrm{E}-15$ & 100.000 & & & & & & \\
\hline
\end{tabular}

Table 6: Rotated Component Matrix ${ }^{\mathrm{a}}$

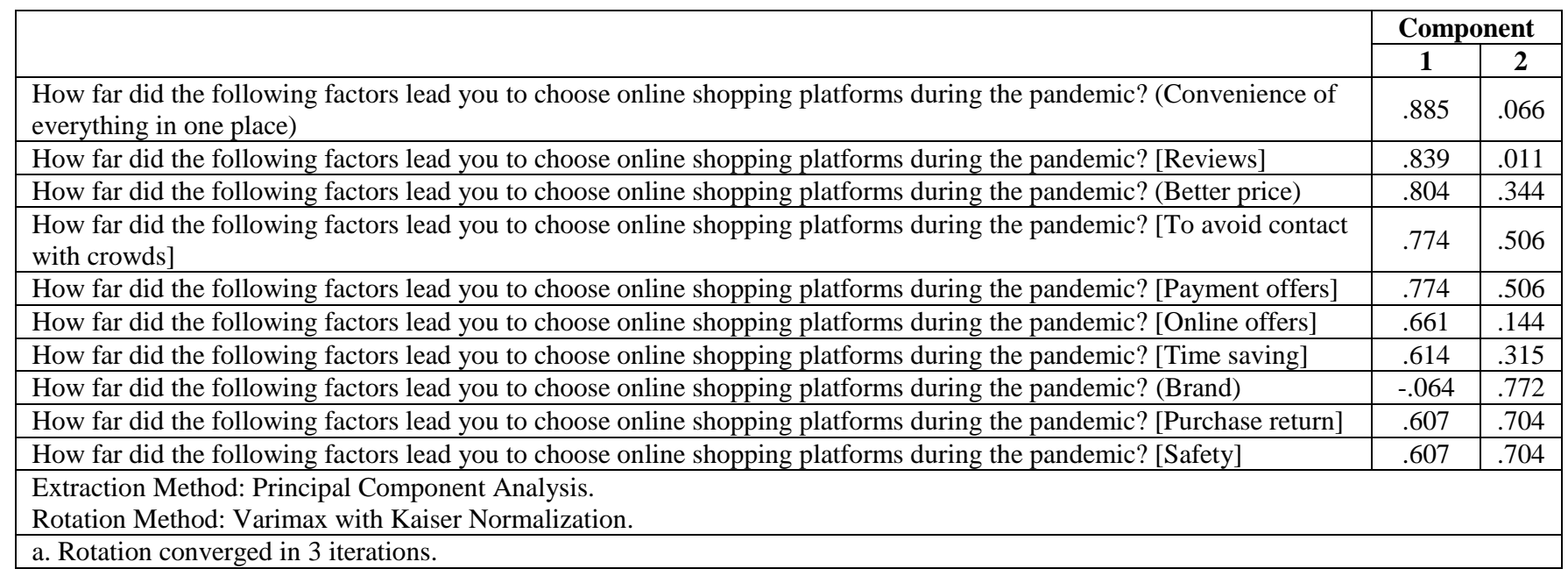

The KMO value is. 749 and Bartlett's test is significant. This indicates that factor analysis is permissible with given data. 10 variables have been reduced to two factors which account for $72.2 \%$ of the variance in the data. The First factor was 'shopping convenience and purchase offers' which included Convenience of everything in one place, Reviews, Better price, to avoid contact with crowds, payment offers, online offers. The second factor was names 'Brand and Safety' included brand, purchase return, safety. Similar studies by Suchitra Rani et al. have assessed that shopping convenience and discounts offered were among the variables that led to online purchase. Discount offers were having greater influence among the other variables found with Convenience coming as the second priority for the same ${ }^{[13]}$.
Study done by Andal et al., showed the correlation among product satisfaction and 8 factors affecting online purchase such as Online buying behaviour, web presentation, price, convenience, product features, quality of the website, ease of finding product and payment method ${ }^{[12]}$. Both these justify the findings of this research paper related to factors that influence purchase decision.

\section{Conclusion}

This study focused on how e-commerce impacted on the consumers post the pandemic period. From chi-square tests it is understood that gender have no influence on choosing the online shopping platform. Covid-19 has increased the importance of online shopping among the consumers due to certain factors like safety, social distancing and all. Previous 
studies in this area have been able to support the findings of this research. Online shopping has made it convenient for the shoppers to buy from any place and at any point of time. Online shopping has brought all kinds of products under one umbrella which has made it easy for shoppers to choose what they want. During this pandemic people have got used and has found online shopping more reliable, safe and easy to use.

\section{References}

1. Digital in India: All the Statistics You Need in 2021 Data Reportal - Global Digital Insights. (n.d.). Retrieved May from, 2021, 5. https://datareportal.com/reports/digital-2021-india

2. Online Shopping: Majority of Indian Consumers May Shift to Online Shopping in Next 9 Months: Survey, Retail News, ET Retail. (n.d.). Retrieved April 2021, from, 2021, 29.

https://retail.economictimes.indiatimes.com/news/ecommerce/e-tailing/majority-of-indian-consumers-mayshift-to-online-shopping-in-next-9-monthssurvey/75367774

3. Chandrakanth Urne, Amoghsiddhi. Impact of ECommerce on Consumer Buying Behaviour: A Review of Existing Literature, 2016.

2016/08/11,https://www.researchgate.net/publication/34 3290488_Impact_of_E-

Commerce_on_Consumer_Buying_Behaviour_A_Revi ew_of_Existing_Literature.

4. Pandey A, Parmar J. Factors Affecting Consumer's Online Shopping Buying Behavior. In Proceedings of 10th International Conference on Digital Strategies for Organizational Success, 2019.

5. Abdelrhim, Mansour, Elsayed, Abdalla. The Effect of COVID-19 Spread on the e-commerce market: The case of the 5 largest e-commerce companies in the world, 2020.

2020/07/22,https://www.researchgate.net/publication/34 3123992_The_Effect_of_COVID-

19_Spread_on_the_e-

commerce_market_The_case_of_the_5_largest_ecommerce_companies_in_the_world

6. Impact of Covid-19 on e-commerce, Orion Market Research Private Limited, ID: 5013567, https://www.researchandmarkets.com/reports/5013567/i mpact-of-covid-19-on-the-e-commerce-market

7. Bhalekar, Vikram, Novel Corona Virus PandemicImpact on Indian Economy, E-commerce, Education and Employment (April 19, 2020). Available at SSRN: https://ssrn.com/abstract=3580342 or http://dx.d oi.org/10.2139/ssrn.3580342

8. Impact of COVID 19 on the E-commerce Market. (n.d.). Retrieved May from, 2021, 4.

https://www.researchandmarkets.com/reports/5013567/i mpact-of-covid-19-on-the-e-commerce-market

9. Nakhate SB, Jain N. The Effect of Coronavirus on E Commerce. Studies in Indian Place Names 2020;40(68):516-518.

10. Hasanat MW, Hoque A, Shikha FA, Anwar M, Hamid ABA, Tat HH. The Impact of Coronavirus (Covid-19) on E-Business in Malaysia. Asian Journal of Multidisciplinary Studies 2020;3(1):85-90.

11. Dr. Haresh B Vaishnani. A Study on Impact of Covid19 Pandemic on Consumer Behaviour - Study Based on
Rajkot City, International Journal of Advanced Research in Commerce, Management \& Social Science (IJARCMSS) 263 ISSN : 2581-7930, Impact Factor: 5.880 2021;04(01):263-270.

12. Andal V, Mythili G. A study of factors affecting online shopping in Chennai. Indian Journal of Public Health Research and Development 2019;10(4):24-28. https://doi.org/10.5958/0976-5506.2019.00658.2

13. Rani TS, Sripathi N. Online Shopping Purchase Patterns with Special Reference to Demographic and Informational Influence. International Journal of Social Sciences and Management 2017;4(1):38-43. https://doi.org/10.3126/ijssm.v4i1.16428 